\title{
A large till wedge in Denmark: implications for the subglacial thermal regime
}

OLE HUMLUM

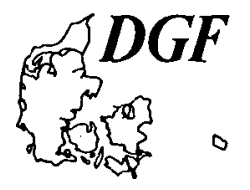

Humlum, O.: A large till wedge in Denmark: implications for the subglacial thermal regime. Bull. geol. Soc. Denmark, vol. 27, pp. 63-71, Copenhagen, October 1st 1978.

https://doi.org/10.37570/bgsd-1978-27-06

A subglacial till intrusion in meltwater sediments is described from a locality in southern Denmark. The structure is interpreted as a large till wedge, developed during glacier flow from the southeast. The intrusion seems to have occurred at a time when the glaciofluvial sediments were unfrozen. The possibility of development of till wedges in frozen sediments is discussed. .

Ole Humlum, Department of Geography, Laboratory of Geomorphology, University of Copenhagen, Haraldsgade 68, 2100 Copenhagen $\emptyset$, Denmark. January 5th, 1978.

Till wedges are subglacial intrusions from the base of a till layer into underlying sediments, often sand. Till wedges trend approximately at right angles to the direction of ice movement with a downglacier dip mostly about $45^{\circ}$ (Dreimanis 1969, Mörner 1972), and may therefore serve as an indicator of the direction of former ice flow. Dionne \& Shilts (1974), however, reported the occurrence of almost vertical till wedges (till dykes) with a slightly convex downglacier curvature. The structures are usually less than $1 \mathrm{~m}$ long (Mörner 1972).

Till wedges are interpreted as fillings of till into frictional cracks formed in frozen sediments by glacial drag (Dreimanis 1969, Mörner 1973a), but squeezing of till into unfrozen sediments has been proposed as well (Mörner 1972, 1973b). The squeezing mechanism is especially thought to account for wedges with irregular shapes. However, Dionne \& Shilts (1974) have argued on a stratigraphical basis that freezing may not in fact be always necessary to form regular cracks. Garnes (1976), who described till wedges from Norway, was of the opinion that till could be injected into unfrozen sediments by liquefaction. Furthermore, Worsley (1973) has drawn attention to the development of till wedge-like structures in other environments - e.g. in a flow till environment. However, the term 'till wedge' should be reserved for wedges formed subglacially (Mörner 1973b).
Previous observations on intrusions of till from Denmark

Hansen (1930) described examples of cracks (several metres deep) in marl and sand, filled with till. He mentioned (p. 396) that the marl appeared to have been exposed to considerable ice pressure, and that the filling of the cracks must have taken place from below. Hansen's findings were later used as a basis for the interpretation of the so-called 'clay-wall' or 'squeeze-up' eskers.

From NE-Sjælland, Berthelsen (1974) described even larger examples of intrusions of till into glaciofluvial sands deformed by ice-push. These intrusions have the form of transgressive sills, irregular dykes and plugs, and have no resemblance with till wedges. Till was intruded from below, while the area was still ice-covered.

Near Sorø, in central Sjælland, an almost vertical till dyke in glaciofluvial sand has been described (Humlum 1976). This dyke is about 0.2 $\mathrm{m}$ wide and at least $2 \mathrm{~m}$ high. Later erosion has truncated the dyke above, but deformations in the stratified drift clearly show that till was intruded from below. Sorting across the dyke furthermore indicates that the till was unfrozen at the time of the event. This intrusion seems to be linked with the melting of buried ice under the fluvial deposits, which were laid down in a meltwater channel.

In the descriptions quoted above, intrusions 


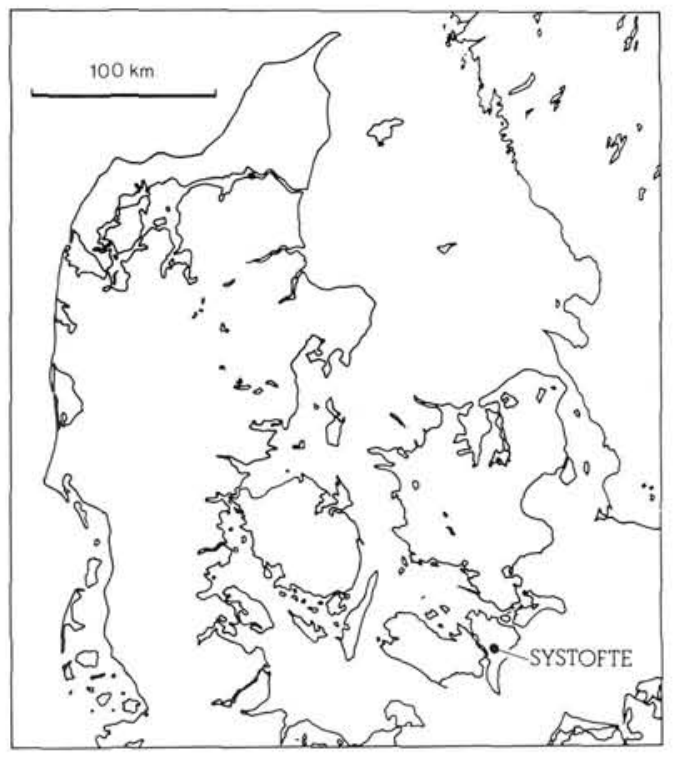

Fig. 1. Location map. are interpreted as having occurred from below; as far as I am aware, no observations of till wedges have been described from Denmark.

\section{A large till wedge in Denmark}

A till intrusion into meltwater deposits was found in a gravel pit near Systofte (fig. 1). This pit has been dug into a N-S trending elongated hill, which rises approximately $10 \mathrm{~m}$ above the surroundings. The hill consists of glaciofluvial sediments, covered by about $2 \mathrm{~m}$ till, poor in structures. The meltwater which deposited the sediments has mainly flowed toward S and SW, and the dominant sedimentary structure is crossbeds (dune-structures). The hill is interpreted as an overridden kame.

According to Milthers (1948), the latest ice movement in this area has been from $\mathrm{E}$ and SE. This is supported by the orientation of several drag folds which are found in the sand underneath the till cover (fig. 2). The deformations do not reach beyond a few metres underneath the till-sand interface. Fold axes have directions between $\mathrm{N} 5^{\circ} \mathrm{E}$ and $\mathrm{N} 30^{\circ} \mathrm{E}$, and the axial planes dip toward $\mathrm{E}$ and $\mathrm{SE}$.

Fig. 2. Drag fold (c, $1.5 \mathrm{~m}$ high) underneath till cover. Viewed toward the northeast.

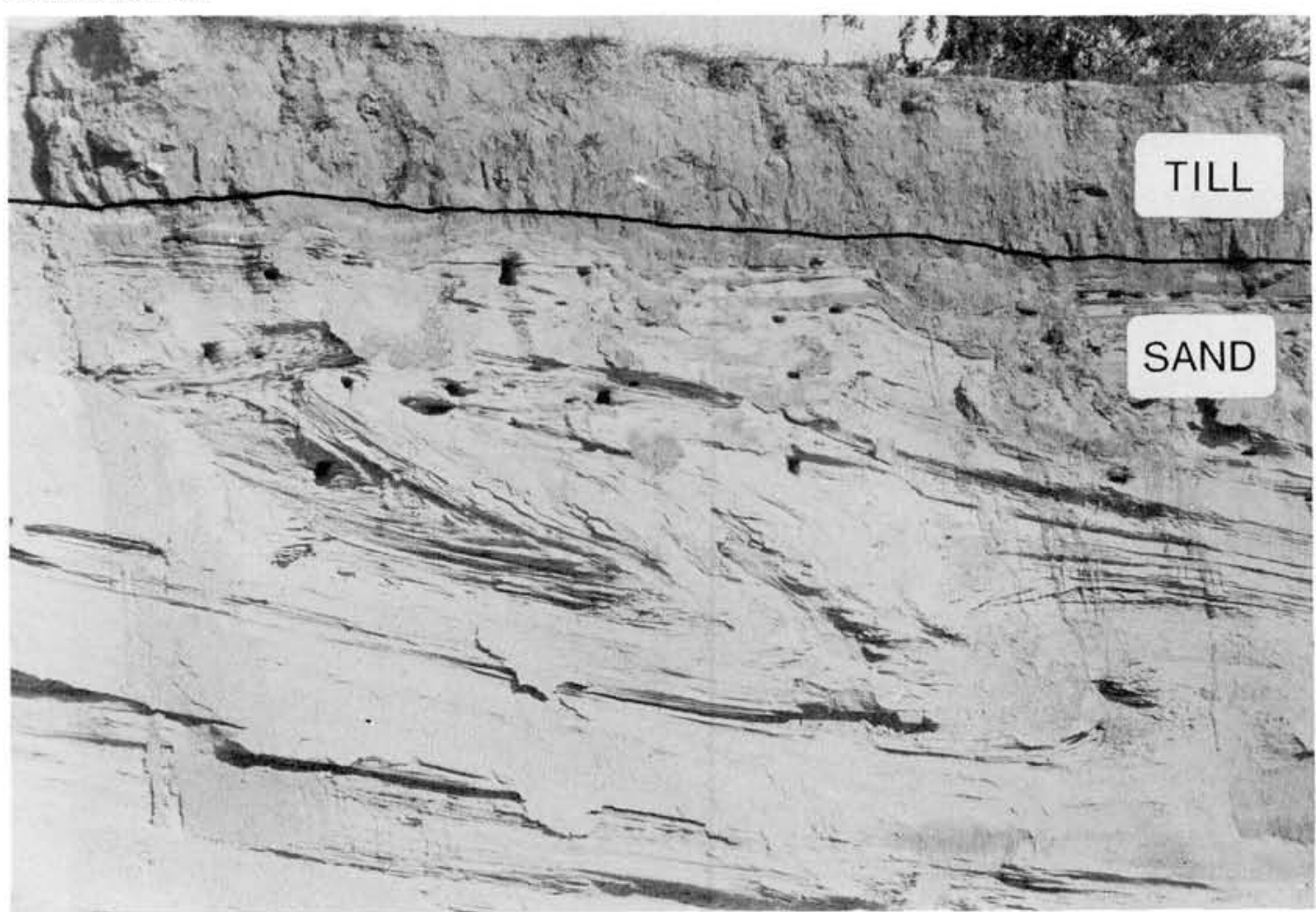


The till cover is interpreted as consisting of lodgement till. The alternative hypothesis is that the cover consists of flow till. However, as the till is massive and poor in structures, and as the drag fold axes only showed slight spreading, this alternative hypothesis is rejected.

\section{Geometry of the intrusion}

Two till wedge-like structures were found in the west wall of the pit (fig. 3). The wedges were coherent with the till cover, and were dipping toward each other in the plan of exposure (N-S). Digging showed that the two wedges merged into each other about $2.5 \mathrm{~m}$ below the base of the till cover. This combined structure was about $1 \mathrm{~m}$ thick where it merged into the upper till, and thinned gradually to only $10 \mathrm{~cm}$ at the lowest point of exposure, where further digging showed that it dipped toward NW. There was no sign of erosion at the level where the intrusive till merged into the till cover.

Fig. 3. Part of the west wall in the gravel pit. The profile is about $10 \mathrm{~m}$ high. The outside parts of the intrusive till structure are seen, dipping toward each other. Viewed toward the northwest.

\section{Deformations}

The intrusive character of the till structure is demonstrated by the fact that it cuts across the bedding in the glaciofluvial sand just below the base of the till cover. Here, the bedding has been exposed to intensive small-scale folding (figs 4 \& 5), with subhorizontal axes having directions between $\mathrm{N} 95^{\circ} \mathrm{E}$ and $\mathrm{N} 120^{\circ} \mathrm{E}$. Deeper, the till intrusion continues parallel to the bedding surfaces, which at this place appear to be deformed (folded) on a larger scale and dip toward W and NW.

The combined till structure is interpreted as a sectional view of a till wedge c. $12 \mathrm{~m}$ wide as shown on fig. 6 . The wedge structure is the only one found in this pit, and this fact, together with the observed dip parallel to the inferred ice movement, makes it unlikely that the structure should be interpreted as an ice-wedge cast. A supraglacial genesis for the wedge structure will not be considered in this paper, because of the intrusive character of the till as mentioned above.

\section{Till fabric}

The macro fabric has been determined at one site in the upper till cover. This analysis, which was carried out for 50 clasts between 0.5 and $10 \mathrm{~cm}$ in

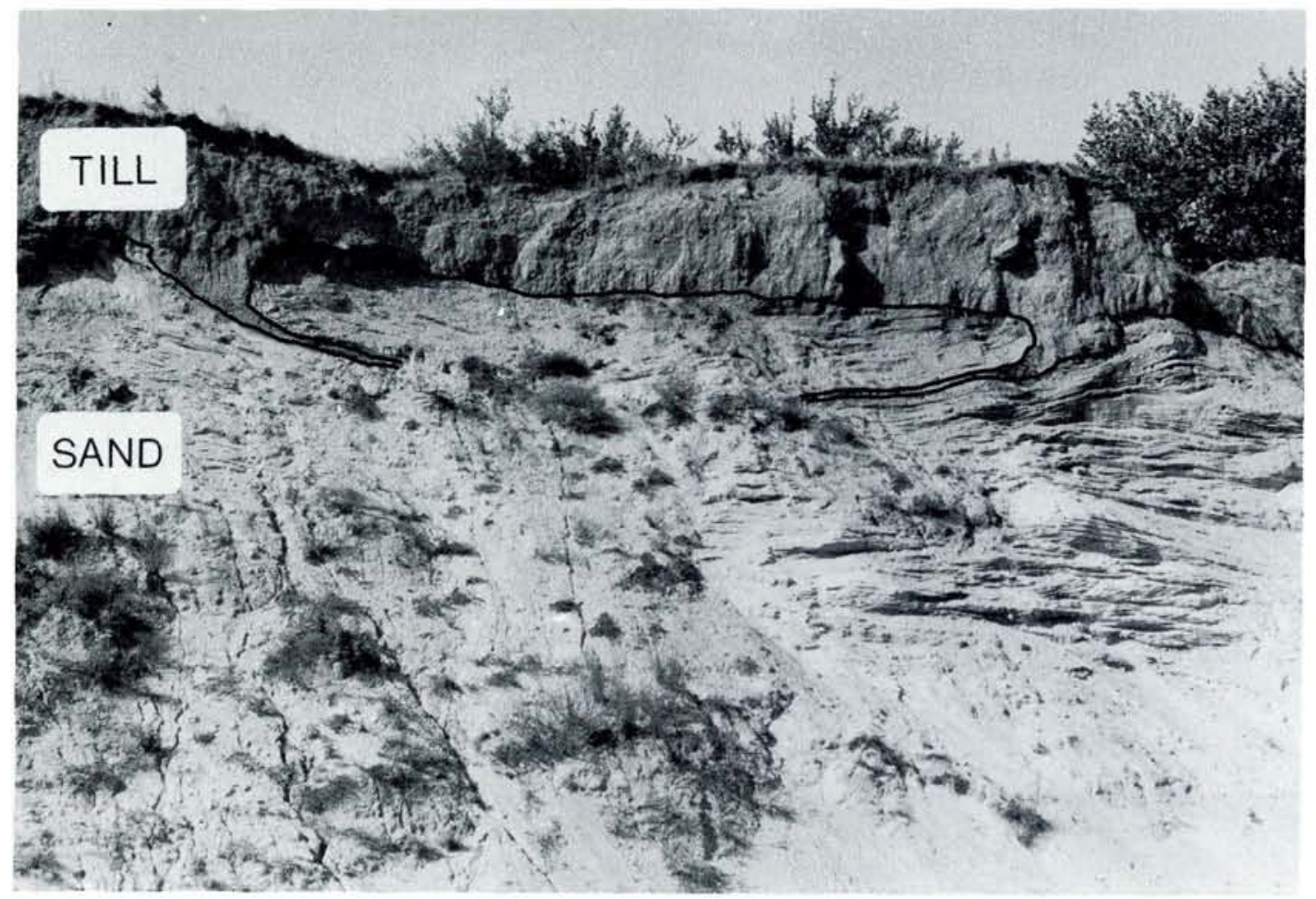




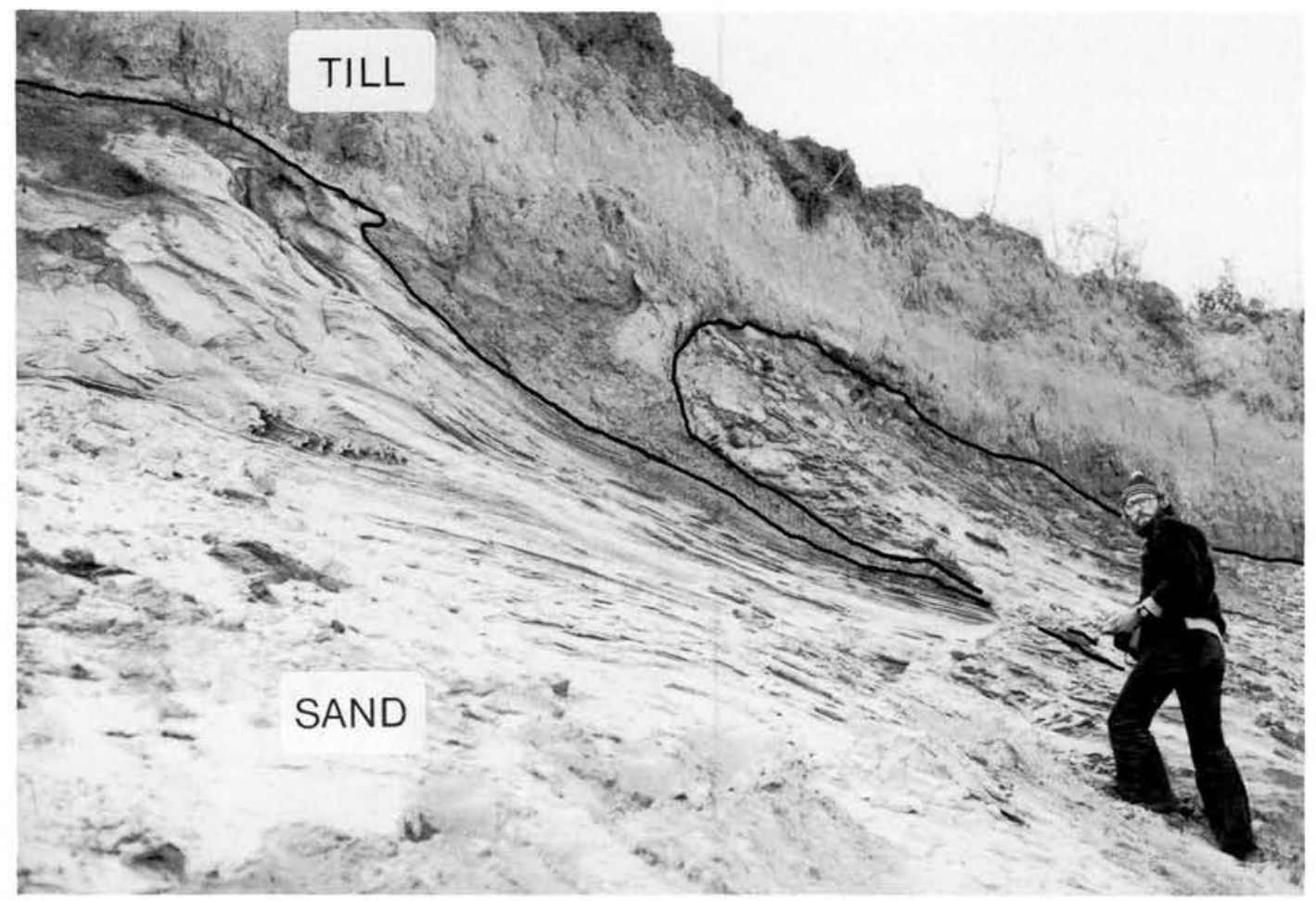

Fig. 4. Southern part of the till structure. Note intensive small-scale folding just south (left) of the structure.

length (axial ratio of at least $1.5: 1: 1$ ), was made halfway between the limbs of the underlying till structure, $10-30 \mathrm{~cm}$ above the base of the till cover. Particles in contact with joints have been avoided.

The result is shown in fig. 7 as a plot of the raw data as well as a contoured diagram. I have adopted contour intervals of one standard diviation for random orientation and a significance level of three standard deviations (Humlum in prep.).

A distinct fabric peak shows up in the diagrams. Ignoring plots outside the upper significance level, the mean dip direction of the density pole is $\mathrm{N} 124^{\circ} \mathrm{E}$ and the mean dip $1^{\circ} \mathrm{NW}$. Therefore, it seems as if no particular change of the south-easterly ice flow has taken place between the folding of the glaciofluvial sand and the deposition of the overlying till.

\section{Texture}

Some mixture with the adjoining sand seems to characterize the outer $1-2 \mathrm{~cm}$ of the wedge, as this zone generally appeared as a sandy till (fig. $8)$. The contact with the fluvial sediments was, however, distinct. Ignoring this marginal zone, the general impression was that the material in the intrusive structure appeared somewhat more fine-grained that the till in the cover above. Two texture analyses were therefore carried out (fig. 9), showing a clear enrichment of particles smaller than $6 \Phi(0.016 \mathrm{~mm})$ in material from the wedge, relative to till taken from the cover. Material from the wedge was sampled across the wedge near the lowest point of exposure, ignoring the sand-enriched marginal zones.

Furthermore, clasts present in the intrusive till. were chiefly found near the central plane of the structure, a characteristic which was especially pronounced in the lowermost part of the structure. Material in a till wedge recorded by Garnes (1976) also seems to display a weak sorting of this kind; this is the case on a large scale, judging from her fig. 16, and p. 29. Garnes further discribed small offshoots from a large wedge, the offshoots displaying central zones of sand and gravel surrounded by more fine-grained material. 


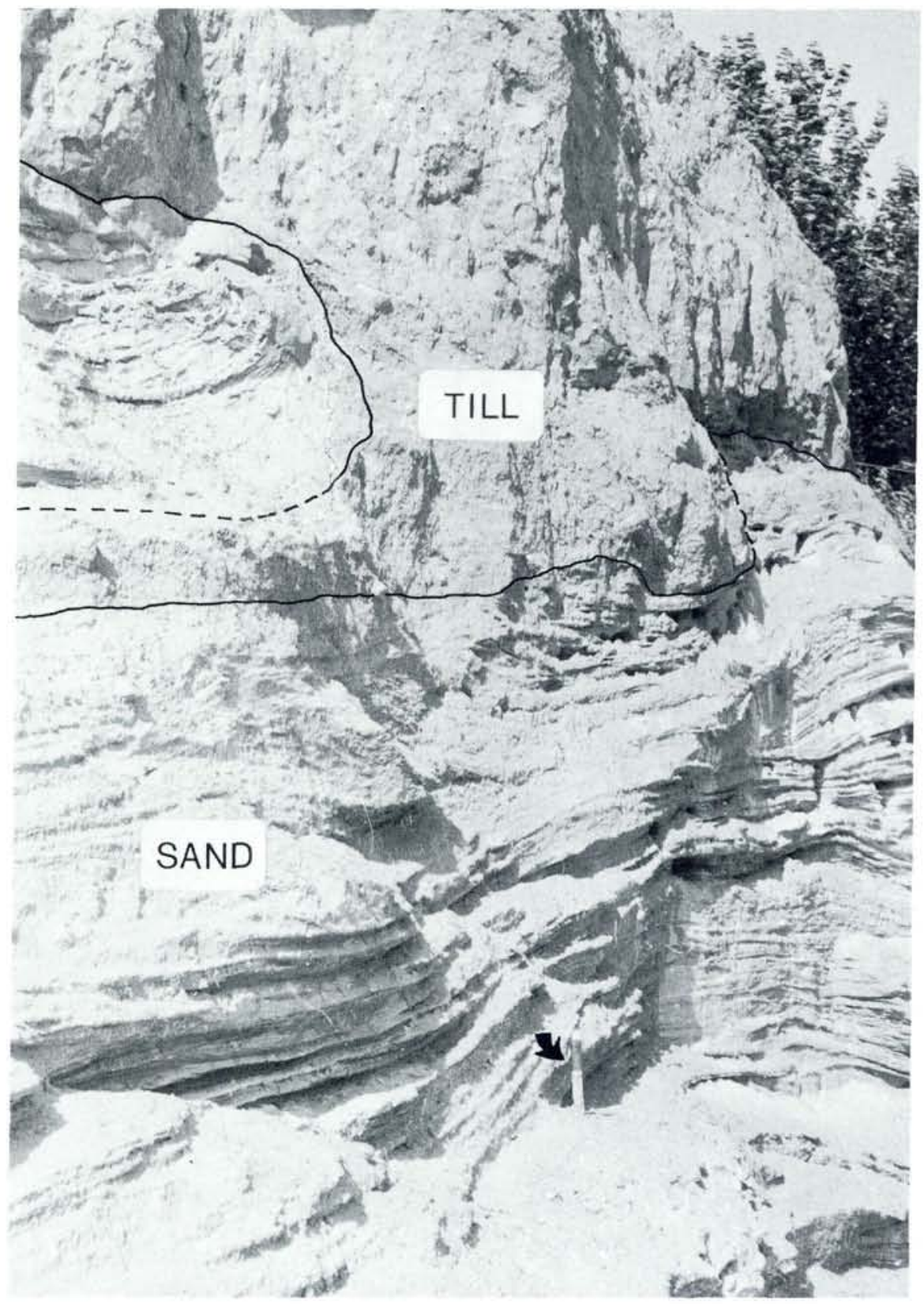

Fig. 5. Northern part of the till structure. The intrusive character of the till is demonstrated by the truncated and folded sand lami-

nations in the upper left. Scale is given by knife (arrow) in the lower central part of the picture. Viewed toward the north.

\section{Discussion of temperature regime}

As there was no sign of erosional contact between the till wedge and the till cover, the material in the wedge most likely originated from the base of the till cover. I would suggest moreover that the internal sorting of till in the wedge and the overall difference in grain-size distribution illustrated by fig. 9, should be explained as a result of the intrusion mechanism, indicating that the till was unfrozen at the time of the event.

The argument for this suggestion is as follows: 


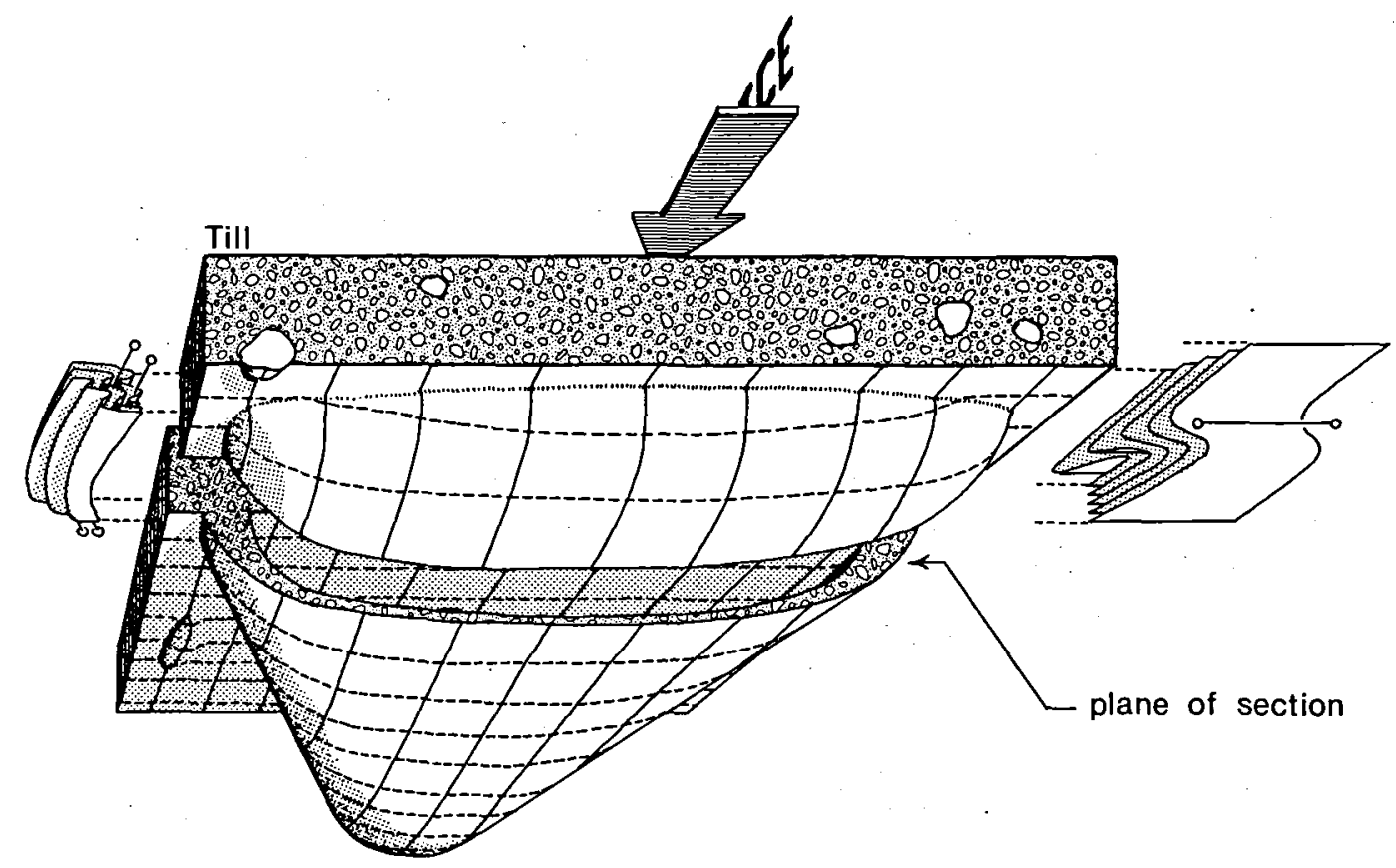

Fig. 6. Interpretation of the till structure seen in fig. 3. Till cover is c. $2 \mathrm{~m}$ thick and the plane of section c. $12 \mathrm{~m}$ wide.

we must expect unfrozen and maybe saturated till to experience considerable shear during flow into a crack in the underlying sediments. In this situation, Bagnold (1954) has shown that the dispersive force acting upon a particle is proportional to the shear rate, suggesting that when a mixture of particles are sheared together, the large particles should drift toward the zone with the least rate of shear. This concept may be used to explain the weak sorting observed across the till wedge, as well as the more overall enrichment of fine particles in the wedge.

Accepting that the till was unfrozen at the time when it was intruded into the wedge structure, the most simple - but naturally not the only possible - supposition is that the sand around the wedge was also unfrozen; a supposition which seems to find some support in the intense folding of the sand as well as the existence of the mixing-zone described from the margins of the till wedge. Thus, the intrusion responsible for the regular till wedge at Systofte is assumed to have taken place at a temperate glacier base.

However, also the alternative hypothesis, subglacial cracking of frozen sediments, should shortly be evaluated. Filling of till into subglacial friction cracks formed in underlying frozen sediments was originally proposed as genesis for till wedges by Dreimanis (1969), but this interpretation has later been questioned by Worsley (1973). Worsley argued that the strength of the frozen ice-sand interface is greater than the yield stress of ice. The rheological properties of frozen ground is a very complex topic, and a thorough review of the mechanics of a sand-ice system is beyond the scope of this paper. It should only be mentioned that the shear strength of a sand-ice system depends upon the amount of ice present in the system, relative to the amount of solid particles, the distribution of ice in the system, the rate of loading, the external pressure and the temperature.

The work and findings of Goughnour \& Andersland (1968) and Hooke et al. (1972) seem to lend support to the criticism presented by Worsley (1973), as do the values for adfreeze quoted by Kaplar (1971). However, fluvial sands usually are characterized by a high porosity $(0.46-0.47$, Kolbuszewski 1950 cf. Allen 1972), and this, in connection with an ice saturation less than $100 \%$, will tend to decrease the strength of a sand-ice system as demonstrated by Alkire \& Andersland 

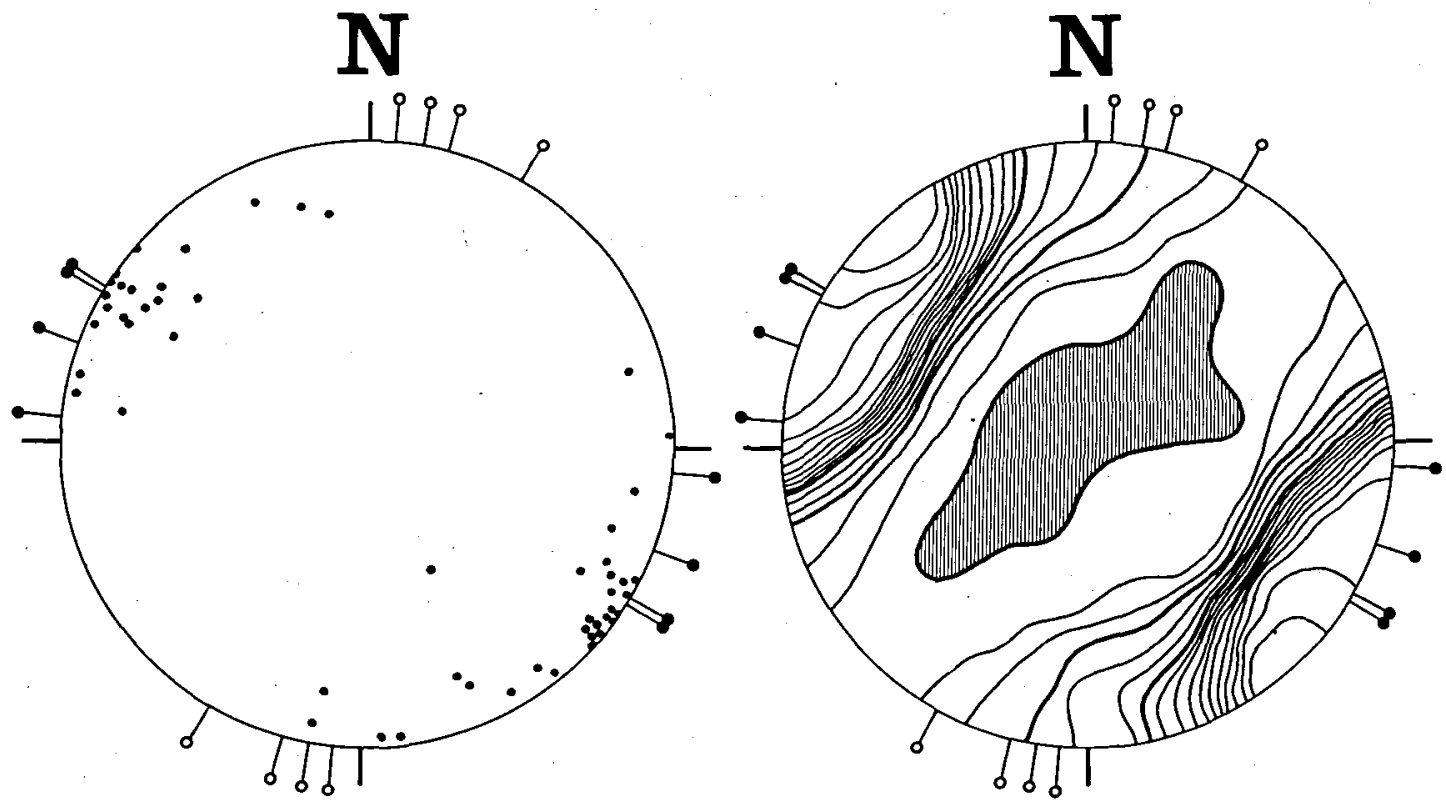

MEAN AZIMUTH: $124^{\circ}$

MEAN DIP : $\quad 1^{\circ} \mathrm{NW}$

Fig. 7. Macro fabric analysis from the till cover. Plot of 50 rod-shaped particles is shown in Wulff projection (stereographic, lower hemisphere). Contour intervals of one standard deviation for random orientation. Statistical parameters are calculated for areas with a density exceeding the density for homogeneous di-

(1973). Therefore, with our present state of knowledge, I consider it impossible to reject the possibility of subglacial plastic deformation as well as fracturing of frozen ground. More work is clearly needed here.

If we accept the possibility of development of a zone with en echelon tension fissures along the interface between the glacier and the bed, as must be inferred from Dreimanis' (1969) theory, the filling of the fractures remains to be explained.

Consider a glacier overriding an area with permafrost. In this glacier, an upward negative temperature gradient will tend to develop. This is a consequence of geothermal heat entering the permafrost layer at the lower boundary and frictional heat generated at the glacier base. To conduct this heat flux upward to the free surface of the glacier, a negative gradient proportional to the flux must develop. This is, of course, a highly simplified situation, and in several cases (e.g. where the surface temperature of the glacier is too high) only a part of the heat flux will be conducted away, and the rest will be consumed by melting ice; partly at the glacier-bed interface, partly at the lower boundary of the frozen ground.

Thus, the frozen ground will tend to thaw and, in the situation outlined, the glacier will not be in direct contact with frozen ground, as must be deduced from Dreimanis' theory. We can therefore conclude, that if the condition inferred from Dreimanis' theory is to be satisfied, all heat must be conducted to the glacier surface. Consequently, a negative temperature gradient will be established from the lower boundary of the permafrost layer to the glacier surface, and this glacier must then be cold rather than temperate at the base.

This conclusion may represent a major obstacle to the theory explaining till wedges as fillings of till into subglacial friction cracks in frozen. ground, as the tendency toward lodgement is ex- 


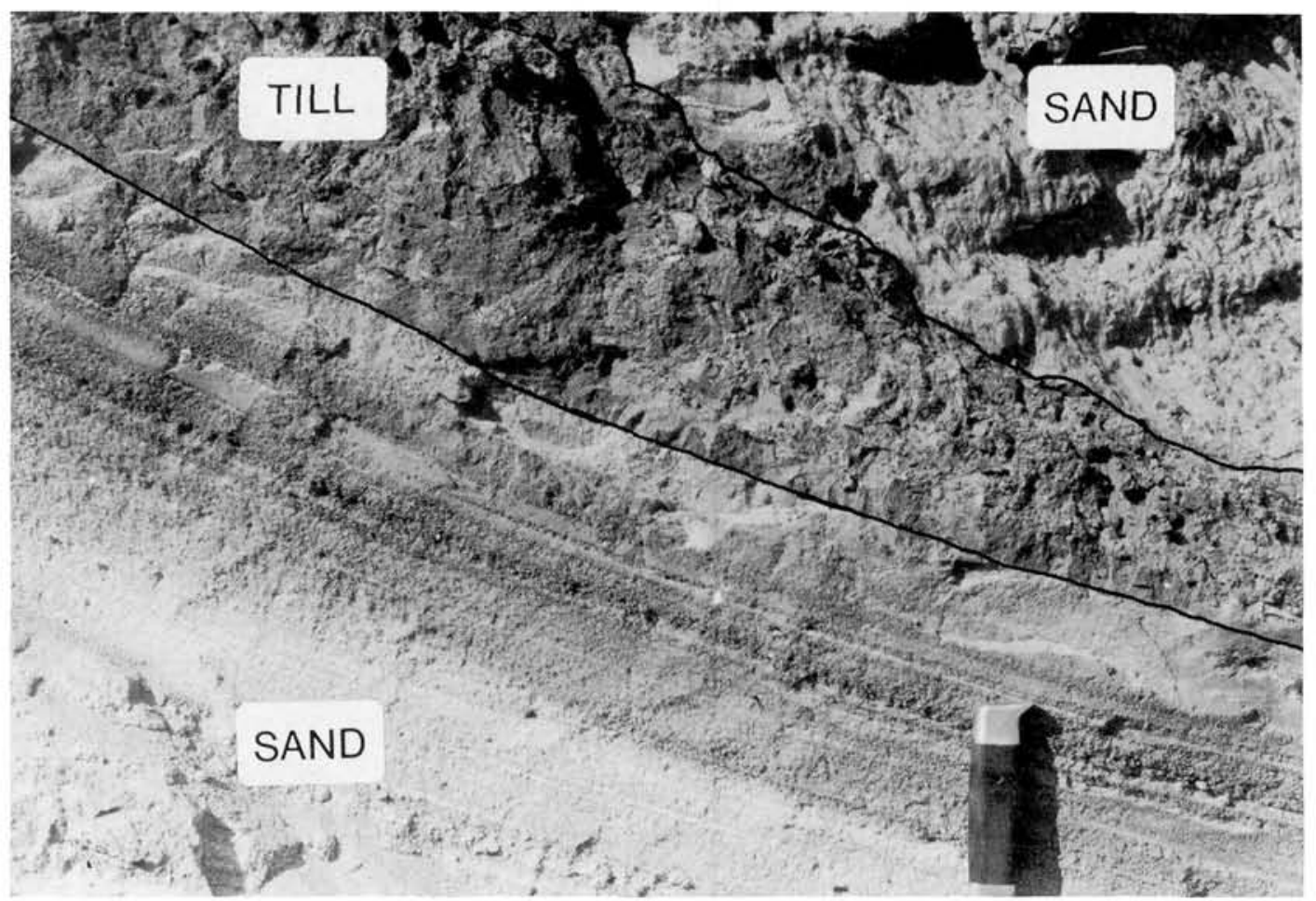

Fig. 8. Detail of the intrusive till structure.

pected to be depressed under cold-based glaciers (Weertman 1961, Boulton 1972). The material necessary for filling of fissures may then be absent, and I suggest that tension fissures at the sole of a cold-based glacier most likely will remain empty until subsequent rotation and closure caused by shear deformation.

\section{Conclusions}

The observations presented on an intrusive till structure, which is interpreted as a large till wedge, indicate that the intrusion took place at a temperate glacier base. From this, however, it is impossible to reach further conclusions concerning the thermal characteristics of the ice sheet, which may have been temperate or alternatively cold with only a temperate base. The ice flow direction was from the SE.

More work is needed on the rheological properties of frozen ground, but with our present knowledge the possibility of subglacial deformation and cracking of frozen ground cannot be rejected. However, thermal considerations indicate that subglacial friction cracks in frozen ground most likely should remain empty until subsequent closure, and it is suggested that this represents an obstacle to Dreimanis' (1969) theory on the origin of till wedges.

Acknowledgements. H. Svensson, J. Krüger, S. Sjörring and N. Foged all kindly read an early draft of the paper. It is a pleasure to thank these persons jointly with Mrs. K. Winther and R. G. Bromley, who improved the English manuscript, and Mrs. W. Eberhardt, who carried out the textural analyses.

\section{Dansk sammendrag}

'Till wedge' eller 'Moränkila' (svensk) er et glacialt retningselement, skabt $\mathrm{i}$ kontaktzonen mellem en aktiv gletschers sål og dennes underlag. I vertikalsnit ses till wedges som intrusioner fra undersiden af en morænebænk ned $\mathrm{i}$ underliggende sedimenter, ofte sand. Till wedges hælder omkring $45^{\circ} \mathrm{i}$ isbevægelsens retning (Dreimanis 1969, Mörner 1972). I horisontalsnit har intrusionen form som et segl, med konveksiteten vendt mod den tidligere isbevægelsesretning.

Sædvanligvis tolkes till wedges som udfyldte friktionssprækker, dannet subglacialt i frosne sedimenter ved gletcherens bevægelse hen over disse (Dreimanis 1969, Mörner 1973a). Mörner $(1972,1973$ b), Dionne \& Shilts (1974) samt Garnes (1976) anfører dog at nogle till wedges kan være dannet $\mathrm{i}$ ufrosne sedimenter. Især Worsley (1973) argumenterer kraftigt imod teori- 

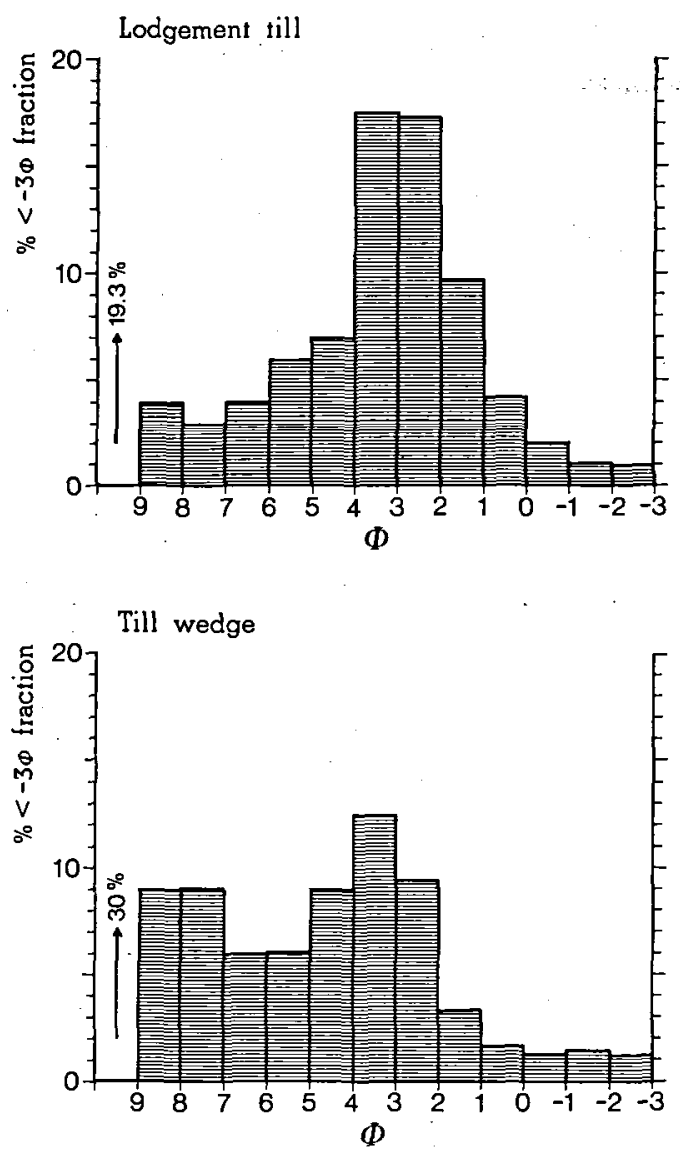

Fig. 9. Textural analyses.

en om dannelse af intrusioner i et frossent underlag, og foreslår istedet at en del till wedge-lignende strukturer kan være dannet i et flow till milieau.

I artiklen beskrives en intrusion af moræneler i smeltevandssedimenter ved Systofte, Falster. Der redegøres for deformationer, fabric, textur og geometriske relationer til den overliggende bænk af moræneler samt til de omgivende smeltevandssedimenter. Det konkluderes at intrusionen er en agte till wed$g e, o g$ at den er dannet på et tidspunkt da lokaliteten var skjult under et isdække i bevægelse fra sydøst mod nordvest. Endvidere konkluderes det at sedimenterne ved gletcherens sål sandsynligvis var ufrosne på dette tidspunkt, $\mathrm{og}$ at isdækket derfor i det mindste ved sålen har været af den tempererede type. Endelig peges på en tilsyneladende generel vanskelighed ved at opfatte till wedges som dannet i frossent gletscherunderlag.

\section{References}

Alkire, B. D. \& Andersland, O. B. 1973: The effect of confining pressure on the mechanical properties of sand-ice materials. J. Glaciol. 12: 469-481.

Allen, J. R. L. 1972: Intensity of deposition from avalanches and the loose packing of avalanche deposits. Sedimentology 18: $105-111$.
Bagnold, R. A. 1954: Experiments on a gravity-free dispersion of large solid particles in a Newtonian fluid under shear. Proc, roy. Soc. London (A) 225: 49-63.

Berthelsen, A. 1974: Nogle forekomster af intrusivt moræneler i NØ-Sjælland. Dansk geol. Foren., Arsskrift for 1973: 118-131.

Boulton, G. S. 1972: The role of thermal régime in glacial sedimentation. Inst. Brit. Geogr. Spec. Publ. 4: 1-19.

Dionne, J.-C. and Shilts, W. W. 1974: A Pleistocene Clastic Dyke, Upper Chaudiere Valley, Québec. Canadian J. Earth Sci. 11: 1594-1605.

Dreimanis, A. 1969: Till wedges as indicators of direction of glacial movements. Abstr. Programs geol. Soc. Amer. Annual. Meeting Atlantic City, 1969: 52-53.

Garnes, K. 1976: Stratigrafi og morfogenese av drumliner på Eigerøya, Rogaland, SV-Norge. Arkeologisk Museum Stavanger Skrifter 1: $53 \mathrm{pp}$.

Goughnour, R. R. and Andersland, O. B. 1968: Mechanical properties of a sand-ice system. Soil Mech. Found. Div. Am. Soc. civ. Engrs. 94 (SM4): 923-950.

Hansen, S. 1930: Om Forekomster af Glacialflager af paleocæn Mergel paa Sjælland. Medd. dansk geol. Foren. 7: 391-410 (summary in German).

Hooke, R. LeB., Dahlin, B. B. and Kauper, M. T. 1972: Creep of ice containing dispersed fine sand. J. Glaciol. 11: 327-336.

Humlum, O. 1976: Sorø-Stenlille-egnens glacialmorfologi, Midtsjalland. Prize essay, Univ. Copenhagen, 383 pp. (unpublished).

Humlum, $O$. in prep.: Graphic presentation and statistical analysis of orientation data in geomorphological studies: a critical review.

Kaplar, C. W. 1971: Some strength properties of frozen soil and effect of loading rate. Cold Regions Research and Engineering Laboratory (CRREL), U.S. Army, special Report 159: 24 pp.

Kolbuszewski, J. 1950: Notes on the deposition of sands. Research 3: 478-483.

Milthers, V. 1948: Det danske Istidslandskabs terrænformer og deres Opståen. Danmarks geol. Unders. (3) 28: 233 pp. (summary in English).

Mörner, N.-A. 1972: The First Report on Till Wedges in Europe and Late Weichselian Ice Flows over Southern Sweden. Geol. Fören. Stockholm Förhandl. 94: 581-587.

Mörner, N.-A. 1973a: A new find of till wedges in Nova Scotia, Canada. Geol. Fören. Stockholm Förhandl. 95: 272-273.

Mörner, N.-A. 1973b: The first report on 'till wedges' in Europe: A reply. Geol. Fören. Stockholm Förhandl. 95: 273-276.

Weertman, J. 1961: Mechanism for the formation of inner moraines found near the edge of cold ice caps and ice sheets. J. Glaciol. 3: 965-978.

Worsley, P. 1973: The first report on 'till wedges' in Europe: A discussion. Geol. Fören. Stockholm Förhandl. 95: 152-155. 